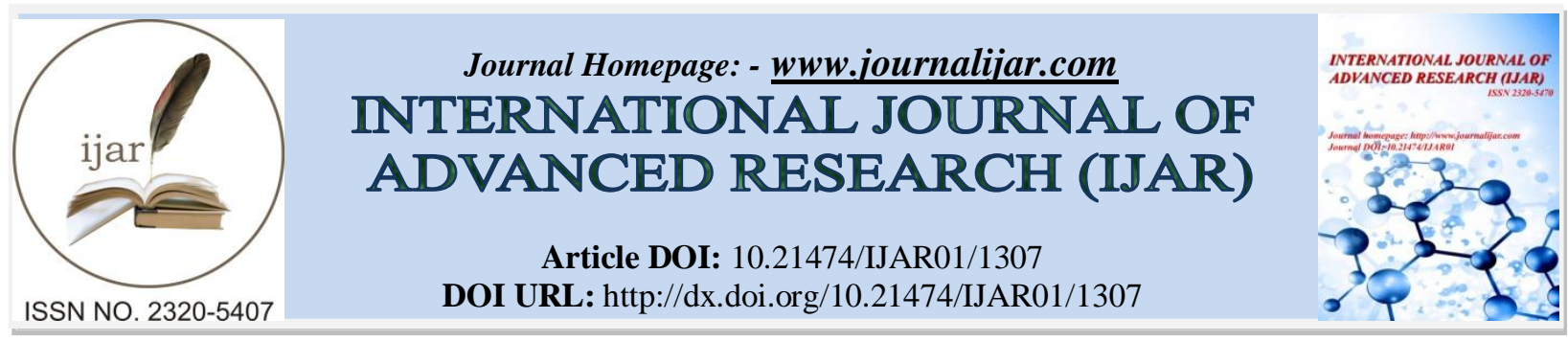

RESEARCH ARTICLE

\title{
ESTIMATION LETHAL DOSE OF SALMONELLA MBANDAKA INOCULATED EXPERIMENTALLY IN MICE.
}

Dept. of Biology, College of Science, Wassit University.

\section{Manuscript Info}

Manuscript History

Received: 15 June 2016

Final Accepted: 19 July 2016

Published: August 2016

Key words:-

Salmonella mbandaka, lethal dose

$\left(\mathrm{LD}_{50}\right)$

\section{Abstract}

Salmonella is an important food borne pathogen worldwide. This study was intended for in vivo to estimation lethal dose of Salmonella mbandaka isolated from human infantile diarrhea by calculating the lethal dose $\left(\mathrm{LD}_{50}\right)$, using mice $(\mathrm{BALB} / \mathrm{c})$ of both gender with age range from 6 to 8 weeks old, which drenched orally. The mice were monitored daily for a maximum of 30 day, the rested fourty two mice were divided randomly into seven groups each of its have 6 mice. The six groups of mice inoculated orally with one of the calculated $(\mathrm{CFU} / \mathrm{ml})$ diluents by using polyethylene tubes about (0.5) $\mathrm{ml}$ and the seven group inoculated Phosphate Buffer Saline $(\mathrm{pH}=7.2)$ and considered as a control group. The lethal dose $\left(\mathrm{LD}_{50}\right)$ of $S$. mbandaka in mice was $\left(1.3 \times 10^{9.5}\right.$ cells $\left./ \mathrm{ml}\right)$.

Copy Right, IJAR, 2016,. All rights reserved.

\section{Introduction:-}

Nontyphoidal Salmonella enterica (NTS) infections are a major burden to global public health, as they lead to diseases ranging from gastroenteritis to systemic infections and there is currently no vaccine available (Ferreira et al ; 2015) . Salmonella spp. pose a threat to both human and animal health, with more than 2600 serovars having been reported to date (Gong et. al, 2016). Salmonella enterica serovars cause a variety of diseases ranging from self-limiting gastroenteritis to severe systemic infections. , virulence of these facultative intracellular pathogens is dependent on their ability to invade and replicate within non-phagocytic cells (DeLeo and Otto, 2008). In vivo Boyle et . al , (2016) referred Salmonella typhimurium cause system accurately modeled key aspects associated with Salmonella enteritis perfused rat small intestinal model, as well as dynamic changes to smooth muscle activity, metabolic competence, and luminal fluid accumulation during short-term infection with the enteropathogenic bacteria. Systemic infections are severe manifestations of salmonellosis; to facilitate systemic infection, intracellular Salmonella present in immune cells such as macrophages and dendritic cells (DC) may be carried from the intestinal tract to other areas of the body(Sundquist et al., 2004). Moreover, the histopathological changes in experimentally in mice inoculated orally with $\left(1.3 \times 10^{7}\right.$ cells / ml $)$ of Salmonella mbandaka have been reported previously (Shallal et. al, 2013). However, clinical signs and gross pathological changes haven't presented. Therefore, this study was designed to study the clinical, bacteriological and gross pathological aspects ( Shallal et. al, 2015). The intraperitoneal route was better than oral route in inducing infection, this may interpret by presence of several barriers in the gastrointestinal tract such as intestinal acidity, competitive by normal flora, secretory $\operatorname{IgA}$ and other barriers but in intraperitoneal route, there were fewer barriers, so large numbers of bacteria must be inoculate orally to induce both infection and death in mice ( AL-Qaisi , 2004) .

Corresponding Author:- Zinah Shakir Shallal.

Address:- Dept. of Biology, College of Science, Wassit University. 


\section{Material and methods:-}

Bacterial isolates:-

Salmonella mbandaka strain from diarrheic child was used for inducing infection, the isolates was obtained from Zoonosis unit in Veterinary College /University of Baghdad ( Shallal et. al , 2015) and isolated according to the standard method according to (Quinn et. al, 2004). This isolate was serotyped in the Central Public Health Laboratories (National Center of Salmonellae in Baghdad).

\section{Experimental mice:-}

The study was carried in the experimental house in the science college of wasit university in Iraq A total of 42 mice $(\mathrm{BALB} / \mathrm{c})$ of both gender with age range from 6 to 8 weeks old, were used in this study. The mice were obtained from the (National Centre of Researches and Drugs Monitor in Baghdad) and adapted for two weeks before experiments. Bacteriological examination showed that the mice were ngative for Salmonella at the beginning of the study. Then divided randomly into 7 groups each with 6 mice. The six groups of mice drenched orally with one of the calculated $(\mathrm{CFU} / \mathrm{ml})$ diluents by using polyethylene tubes about $(0.5) \mathrm{ml}$ and the seven group drenched PBS ( $\mathrm{pH}=7.2)$ and considered as a control group. . All groups were observed for 30 days to calculate the live and dead mice and determine lethal dose according to (Reed and Muench, 1938).

\section{Details regarding the experiments are as follow:-}

\section{Determination of lethal dose $\left(\mathbf{L D}_{50}\right)$}

Each five colonies of $S$. mbandaka was inoculated in $(10 \mathrm{ml})$ of Brain heart infusion broth at $37{ }^{\circ} \mathrm{C}$ for (18) hours then centrifuged in cooling centrifuge (8000) rpm (round per minute) for (15) minutes then the sediment (pellet) after washing three times with PBS ( $\mathrm{pH}=7.2)$ was suspending by using (1) $\mathrm{ml}$ of $\mathrm{PBS}(\mathrm{pH}=7.2)$ and ten fold dilution $\left(10^{-1}, 10^{-2} \cdot 10^{-3}, 10^{-4}, 10^{-5}, 10^{-6}, 10^{-7}, 10^{-8}, 10^{-9}\right.$ and $\left.10^{-10}\right)$ were done. The viable count of the bacteria in each diluent was made according to method of Miles and Misra, (1938) and dilution which contain $\left(1.3 \times 10^{9.5}\right.$ cells $\left./ \mathrm{ml}\right)$ was consider as lethal dose .

\section{Ethical improvement:-}

This study was approved by the ethical and research committee of Veterinary Medicine College/University of Baghdad and Science College/University of Wasit .

\section{Statistical analysis:-}

Chi square was conducted to determine the statistical differences among the tested groups by using SPSS statistical program (ready-made statistical design).

\section{Result and discussion:-}

The results of this study revealed that the lethal dose $\left(\mathbf{L D}_{\mathbf{5 0}}\right)$ of Salmonella mbandaka in mice was $\left(1.3 \times 10^{9.5}\right.$ cells). The $\mathrm{LD}_{50}$ was estimated by calculating the dead and alive mice in each group during (30) days of the experiment (Table 1).

Table 1:- Calculation of $\mathrm{LD}_{50}$ of Salmonella mbandaka isolated from human in mice .

\begin{tabular}{|c|c|c|c|c|c|c|c|c|}
\hline \multirow[b]{2}{*}{ Groups } & \multirow{2}{*}{$\begin{array}{c}\text { Dilution of } \\
\text { bacteria }\end{array}$} & \multirow[b]{2}{*}{$\begin{array}{c}\text { Dose } \\
\text { (cells) }\end{array}$} & \multicolumn{2}{|c|}{ Observed values } & \multicolumn{2}{|c|}{ Accumulated values } & \multicolumn{2}{|c|}{ Rates } \\
\hline & & & Dead & Live & $\begin{array}{l}\text { Total } \\
\text { dead }\end{array}$ & Total live & $\begin{array}{c}\text { Fractional } \\
\text { ratio }\end{array}$ & $\begin{array}{c}\text { Percent } \\
\text { ratio }\end{array}$ \\
\hline 1 & $10^{-2}$ & $1.3 \times 10^{11}$ & $6 / 6$ & $0 / 6$ & 14 & 0 & $14 / 14$ & $100 \%$ \\
\hline 2 & $10^{-3}$ & $1.3 \times 10^{10}$ & $4 / 6$ & $2 / 6$ & 8 & 2 & $8 / 10$ & $80 \%$ \\
\hline 3 & $10^{-4}$ & $1.3 \times 10^{9}$ & $3 / 6$ & $3 / 6$ & 4 & 5 & $4 / 9$ & $44 \%$ \\
\hline 4 & $10^{-5}$ & $1.3 \times 10^{8}$ & $1 / 6$ & $5 / 6$ & 1 & 10 & $1 / 11$ & $10 \%$ \\
\hline 5 & $10^{-6}$ & $1.3 \times 10^{7}$ & $0 / 6$ & $6 / 6$ & 0 & 16 & $0 / 16$ & $0 \%$ \\
\hline 6 & $10^{-7}$ & $1.3 \times 10^{6}$ & $0 / 6$ & $6 / 6$ & 0 & 22 & $0 / 16$ & $0 \%$ \\
\hline 7 & PBS & - & $0 / 6$ & $6 / 6$ & 0 & 28 & $0 / 16$ & $0 \%$ \\
\hline
\end{tabular}

No. of mice in each group $=6$

Total No. of mice $=42$

The percentage of mortility was calculate according to the method of Reed and Munch, (1938). Proportional distance $=\%$ mortality above $50 \%-50 \% / \%$ mortality above $50 \%-$ mortality below $50 \%$. 
The lethal dose of Salmonella mbandaka was $\left(1.3 \times 10^{9.5}\right.$ cells / $\left.\mathrm{ml}\right)$ obtained in this work, indicated that the strong of virulence of this isolate as it cause localized infections. The rout of infection in the present experiment was inoculated orally. The result was very large dose when compared with that mentioned by Yousif, (2000) and AlHashimi, (2005) which referred that the $\mathrm{LD}_{50}$ of S. typhimurium and S. enteritidis in mice were $\left(2 \times 10^{6} \mathrm{CFU} / \mathrm{ml}\right)$, $\left(1.4 \times 10^{6} \mathrm{CFU} / \mathrm{ml}\right)$ respectively. Mikula et al., (1988) found that post oral infection of calves with $S$. typhimurium $4 / 5$ strain at a dose $\left(1 \times 10^{6}\right.$ C.F.U./ml), there was discontinuous and irregular of the brush border membrane of jejunal enterocyte. In contrast, this result with Shallal, (2013) who injected an intra-peritoneal (I.P) $\mathrm{BALB} / \mathrm{c}$ mice for typical (eae $A+, b f p+)$ and atypical (eae $A+, b f p-)$ enteropathogenic Esherichia coli reported $\mathrm{LD}_{50}$ of them were $\left(1 \times 10^{8.6} \mathrm{CFU} / \mathrm{ml}\right)$ and $\left(1 \times 10^{7} \mathrm{CFU} / \mathrm{ml}\right)$ respectively, and with Benedict and Flamiano , (2004) were used mice models to determine the minimum lethal dosage (MLD) of $E$. coli found to be an intraperitoneal (I.P) injection of $0.5 \mathrm{ml}$ of $10^{7} \mathrm{CFU} / \mathrm{ml}$ as it induced fatality in all replicates within $24 \mathrm{hrs}$. These results are approximate with the study by Yousif and Al-Naqeeb, (2010) reported that the LD 50 of Salmonella hadar drenched orally in mice was $\left(1.5 \times 10^{9} \mathrm{CFU} / \mathrm{ml}\right)$, also with Al-Mansory, (2009) determined the lethal dose of Salmonella enteritidis in rabbits was $\left(2 \times 10^{10} \mathrm{CFU} / \mathrm{ml}\right)$.

\section{Conclusion:-}

It could be concluded these data shows that it takes a very low number of microorganisms to cause illness in young children, the elderly and immune - compromised people. As it is obvious from the results mentioned above , Salmonella mbandaka did not differ significantly from other nontyphoid Salmonella spp. for all this study included criteria, which means that $S$. mbandaka have the same virulence for mice inoculated orally .

\section{Acknowledgments:-}

The author is grateful to Head of Dep. of Internal Preventive Medicine / College of Vet. Med. / University of Baghdad and Head of Biology Department/College of science/ Wasit University for their kind support during conducting this study.

\section{Refrences:-}

1. AL-Hashimi, L.J.M. (2005). Study of some Pathological and Immunological Aspects of S. enteritidis in Mice . M.Sc. thesis, Vet. Med. College/Baghdad University- Iraq (in Arabic language).

2. Al-Mansory, S.H.H. (2009). Preparation of some Salmonella enteritidis antigens isolated from goats and study the immune efficacy of them in Rabbits . M.Sc. thesis, Vet. Med. College / Baghdad University - Iraq.

3. AL-Qaisi, M.K. (2004). Pathological and immunological changes for bacillary dysentery bacteria in mice and guinea pigs . Ph. D thesis, Vet. Med. College/Baghdad University- Iraq (in Arabic language).

4. Benedict L.R. Non , M.D. and Flamiano R. M.S.(2004). Use of bacteriophages as therapy for Escherichia coli-induced bacteremia in mouse models. Infect Dis. 33(2):47-51 .

5. DeLeo, F. and Otto, M. (2008). Bacterial Pathogenesis" Methods and Protocols, in Methods in Molecular Biology, Humana Press, a part of Springer Science+Business Media, LLC.

6. Ferreira RB, Valdez Y, Coombes BK, Sad S, Gouw JW, Brown EM, Li Y, Grassl GA , Gill N, Truong M, Scholz R, Reynolds LA, Zafer AA, Sal-Man N, Lowden MJ , Auweter SD, Foster LJ , Finlay BB . (2015 ). A Highly Effective Component Vaccine against Nontyphoidal Salmonella enterica Infections. MBio. Sep 22;6(5):e01421-15.

7. Gong J., Zhuang L ., Zhu C ., Shi S ., Zhang D ., Zhang L., Yu Y ., Dou X . , Xu B ., Wang C . 2016 ) . Loop-Mediated Isothermal Amplification of the sef A Gene for Rapid Detection of Salmonella enteritidis and Salmonella gallinarum in Chickens. Foodborne Pathog Dis. Apr;13(4):177-81. doi: 10.1089/fpd.2015.2082.

8. Mikula, E. ; Pilipeinec, I. and Timkovicova, M. (1988). Electro-microscopic studies of the intestinal tract in calves after experimental Salmonella infection . Folia. Vet., 32: 70-97.

9. Miles, A.A. and Misra, S.S. (1938). The estimation of the bactericidal power of blood . J. Hyg. 38: 732-749.

10. Quinn, P.J.; Markey, B.K.; Carter, M.E.; Donnelly, W.J. and Leonard, F.C.(2004). Veterinary Microbiology and Microbial Diseases. 1st Ed., Blackwell Science Ltd.

11. Reed, L .J. and Muench, H. (1938). A simple method of estimating fifty percent end point . Am. J. Hyg., 27(16): 8739-8744.

12. Shallal Z S, Yousif AA, Faleh EB (2013). Histopathological changes in the Intestine and lung of mice infected experimentally with Salmonella mbandaka. Mirror of Research in Veterinary Sciences and animals (MRVSA). $2(2), 47-53$. 
13. Shallal Z. S. (2013). In vivo comparison of virulence of typical and atypical Enteropathogenic Esherichia coli isolated from human infantile diarrhea . Wasit Journals for Science and Medicine 6(2):(102-108) .

14. Shallal Z. S., Yousif A. A. and Al-Deresawi (2015). Salmonella mbandaka isolated from human: Clinical and gross pathological studies in experimentally infected mice. MRVSA 4(1), 27-38.

15. Sundquist, M. ;Rydstrom, A. and Wick, M.J. (2004). Immunity to Salmonella from a dendritic point of view . Cell Microb., 6: 1-11.

16. Yousif AA, Alshemmari IG M., Mahdi. MS.(2011). Epidemiological study on Salmonella spp isolated from goat in some provinces in middle of Iraq. Iraqi Jou. of Science.Vol 51, No 3).

17. Yousif, A.A. and AL-Naqeeb, M.N. (2010). Ultrastructural Changes in the Ileum of White BALB/C Mice Experimentally Infected with Salmonella hadar. American Journal of Animal and Veterinary Sciences 5 (3): 196-201. 